\title{
Effect of varietal difference on the proximate, functional and sensory properties of melon seeds
}

\author{
Akusu O. M.* and Emelike N. J. T. \\ Department of Food Science and Technology, Faculty of Agriculture, Rivers State University, Port Harcourt, Nigeria. \\ ${ }^{*}$ Corresponding author. Email: akusu.monday@yahoo.com
}

Copyright (@ 2018 Akusu and Emelike. This article remains permanently open access under the terms of the Creative Commons Attribution License $\underline{4.0}$, which permits unrestricted use, distribution, and reproduction in any medium, provided the original work is properly cited.

Received 11th November, 2018; Accepted 29th November, 2018

\begin{abstract}
The study was carried out to evaluate the effect of varietal difference on the proximate, functional and sensory properties of four varieties of melon seeds such as Cucumis melo, Cucumeropsis manii, Citrullus colocynths and Citrullus vulgaris. The proximate result showed that protein, fat, ash, moisture, crude fibre and carbohydrate contents of the melon seeds ranged from 30.37 to $34.81 \%, 47.14$ to $52.52 \%, 2.57$ to $4.40 \%, 4.30$ to $6.26 \%, 3.92$ to $5.51 \%$ and 0.11 to $3.16 \%$, respectively. There were significant differences $(p<0.05)$ in the values obtained for protein, ash and crude fibre contents. Bulk density, Oil and water absorptions of the melon seed varieties ranged from 0.54 to $0.67 \mathrm{~g} / \mathrm{g}, 2.10$ to 2.55 $\mathrm{g} / \mathrm{ml}$ and 1.26 to $1.45 \mathrm{~g} / \mathrm{ml}$, respectively. Sensory analysis of the egusi soups prepared from the melon seed varieties indicated that soup of Citrullus vulgaris was most preferred than other varieties in terms of appearance (8.07), taste (7.80), flavour (7.40), water separation (7.67), thickness (8.07), as well as overall acceptability (7.93) and showed no significant differences ( $p>0.05$ ) with Cucumis melo and Citrullus colocynths. The results showed that the four melon seed varieties contain appreciable quantities of protein, ash and fat with functional properties that are favourable for human consumption and for industrial applications. Higher premium should therefore be placed on the consumption of Cucumis melo and Citrullus colocynths as they can be used to replace Citrullus vulgaris in the preparation of egusi soup.
\end{abstract}

Keywords: Egusi soup, food condiment, high premium, melon seed, soup preparation, varietal difference.

\section{INTRODUCTION}

Melon is a creeping annual plant belonging to the Curcurbitaceae family with a fibrous and shallow root system. They thrive best in the hot climate regions of Africa and can be grown on rich light soil (Akpambang et al., 2008). The seed has an increasing demand since they contribute greatly towards achieving a balanced diet (Fokou et al., 2004). They have good quantities of sulphur, calcium, potassium, magnesium, phosphorus and manganese. They are necessary in the diets as they have high nutritive and caloric values. Akusu and Kiin-kabari (2015) reported that melon seed (egusi) contains $9.30 \%$ moisture, $3.33 \%$ ash, $42.89 \%$ fat, $25.36 \%$ protein, $3.83 \%$ fibre and $15.31 \%$ carbohydrate. Melon seeds are known to have therapeutic effects such as antioxidant, antiinflammatory and analgesic effects in the human body (Chen et al., 2014). In Nigeria and other parts of the world, they are used to prepare food condiment with a characteristic aroma. They can also be used as a flavouring and thickening agents in stews, soups and sauces (Onyeike and Achera, 2002). "Ogiri" is a locally fermented melon popularly used among the lgbo part of Nigerian tribe as a food condiment to season or flavour soup (Yusuf et al., 2006).

There are numerous varieties of melon seeds. However, the suitability of these melon species to be used in soup preparation depends on their properties. Variety is the principal factor contributing to food quality (Ogbuonye, 2017). Citrullus vulgaris has been of increasing demand amongst the melon species. This variety of melon is mainly consumed and cherished more than other varieties. It is becoming very expensive in Nigeria whereas other varieties of melon are underutilised as food. Other varieties of melon can be used thereby reducing the cost of egusi soup preparation. Furthermore, there has been 
compliant from wives and caterers on different sensory qualities of melon seeds used in the preparation of egusi soups. They tend to be confused on the best type of melon seeds to be use in soup preparation. Thus, the provision of empirical data on the proximate, functional, sensory properties and nutritional values of some underutilised plants of the melon species is desirable. This will go a long way in creating awareness and improve the consumption rate of these plants. It will establish quality parameters of different varieties of melon seeds and enhances the usage of the best variety for human and industrial consumption.

Several researches on the chemical and functional properties of some melon seed varieties have been reported (Ogundele and Oshodi, 2010; Egbebi, 2014; Jacob et al., 2015) while sensory properties of these melon seed varieties have not been given much attention by the researchers. Hence, this study aimed to analyse the effect of varietal differences on the proximate, functional and sensory properties of melon seeds to determine their suitability in soup preparation.

\section{MATERIALS AND METHODS}

\section{Materials}

Four varieties of melon seeds namely; Cucumis melo (plate 1), Cucumeropsis manni (plate 2), Citrullus colocynths (plate 3) and Citrullus vulgaris (plate 4) were purchased from daily market, Obowo, Port Harcourt, Rivers State and transported to the Department of Food Science and Technology Laboratory at Rivers State University, Port Harcourt, Nigeria for processing. Stock fish head, chili pepper, dry fish and magi cubes used for stock preparation were purchased from Mile 3 market in Port Harcourt, Nigeria. All chemicals used were of the analytical grades, products of BDH chemical Ltd pool, England and obtained from the same mentioned Laboratory.

\section{Methods}

\section{Preparation of melon seed flour}

Five kilogram $(5 \mathrm{~kg})$ of melon seeds were shelled, sorted, cleaned and oven dried at $50^{\circ} \mathrm{C}$ for $12 \mathrm{~h}$ in a hot air fan circulating oven (model QUB, 305010G, Gallenkamp, U.K), milled to pass through a $0.25 \mathrm{~mm}$ British standard micron particle size sieve (Model B5410, Endecoths Ltd, London, UK), as shown in Figure 1.

\section{Proximate analysis of melon seed flours}

Moisture, ash, crude fibre and fat contents were determined according to the method described by AOAC (2012). Crude protein was calculated from the nitrogen content by Kjeldahl method using factor 6.25 as described by AOAC (2012) and total carbohydrate content was calculated by difference.

\section{Functional analysis of melon seed flours}

Bulk density was determined using Arisa et al. (2013) method, Water absorption was determined as described by Elkhalifa et al. (2005), Oil absorption capacity and least gelation concentration capacity were determined using the methods of Sathe and Salunkhe (1981).

\section{Preparation of Egusi soups}

The method of Kiin-Kabari and Akusu (2017) was used in the preparation of soups from melon seed flours with some modifications. Five hundred grams $(500 \mathrm{~g})$ of melon seed flour samples were used in the soup preparation based on the recipe formulation as shown in Table 1. After preparation of stock using stockfish, dry fish, magi and pepper, palm oil was heated in a pot for 2 min, finely chopped onion was added and allowed to steam for $1 \mathrm{~min}$; the egusi seed flour was added and allowed to steam for 15 min with continuous stirring to prevent it from burning. Four hundred milliliters $(400 \mathrm{ml})$ of the prepared stock was added together with $10 \mathrm{~g}$ of salt and allowed to boil for 20 $\mathrm{min}$. The soup was then allowed to cool for $20 \mathrm{~min}$ after which sensory evaluation was conducted on the soup samples.

\section{Sensory evaluation}

Twenty panelists that are familiar with egusi soup were selected for the sensory evaluation of the egusi soup prepared from each variety of the melon seed samples. A 9-point Hedonic scale was used to evaluate the appearance, taste, flavour, water separation, thickness and overall acceptability of the prepared soups. The sensory scales ranged from 9 to 1 representing like and dislike extremely, respectively and the middle of the scale which is 5 represented neither like nor dislike. The panelists were served with the egusi soup in the Food and Nutrition Laboratory of the Food Science and Technology Department, Rivers State University at room temperature $\left(28 \pm 2^{\circ} \mathrm{C}\right)$. Table water was provided for the panelists for rinsing their mouth to prevent transfer of sensory parameters from one sample to another.

\section{Statistical analysis}

The data obtained were subjected to Analysis of Variance (ANOVA) using Statistical Package for Social Sciences (SPSS) version 20.0, software 2011. All analysis was conducted in duplicate and means separated using Least Significant Difference Test (L.S.D). 


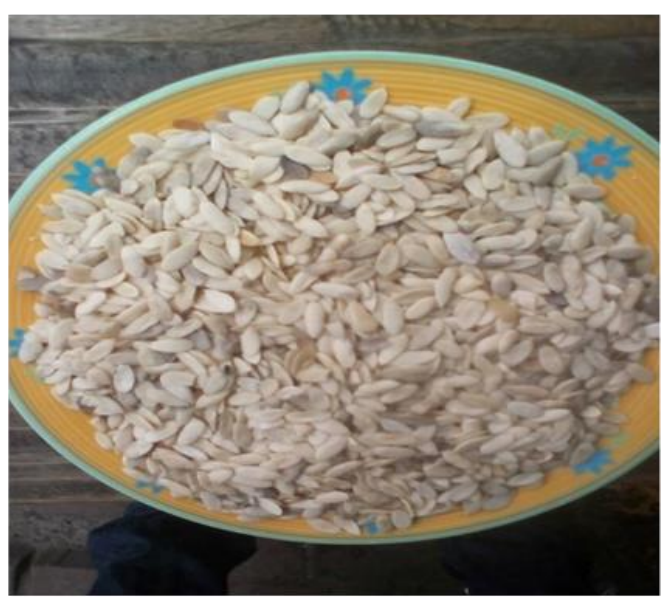

Plate 1: Cucumeropsis melo

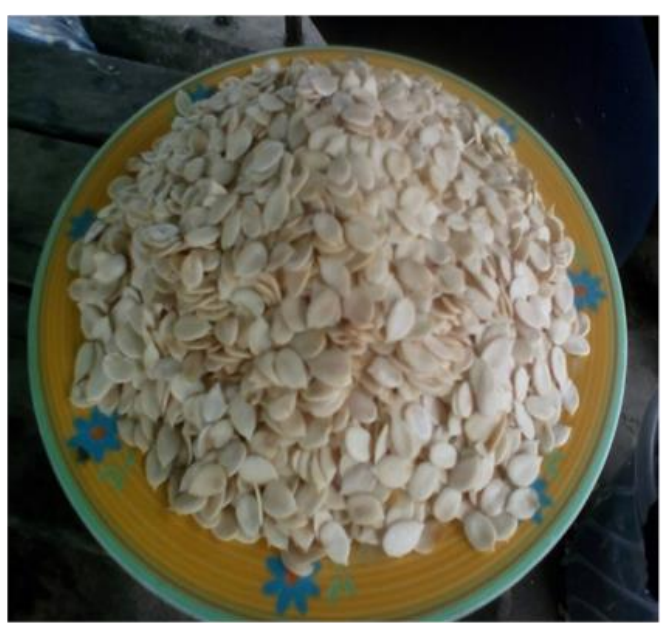

Plate 3: Citrullus colocynths

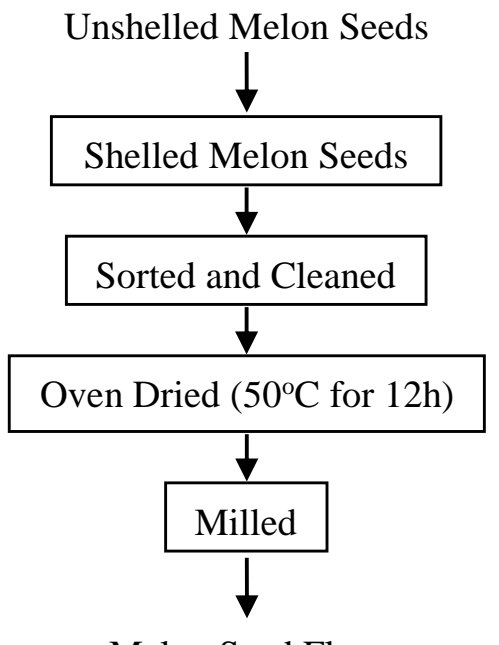

Melon Seed Flour

Figure 1. Flow chart for the processing of melon seed into flour.

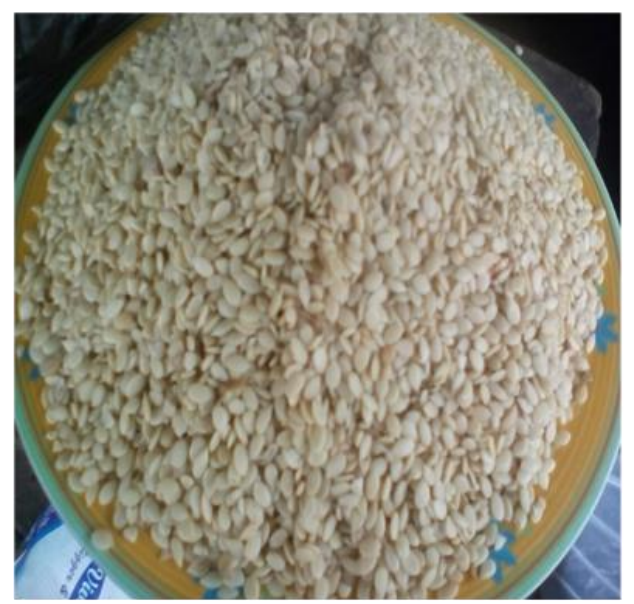

Plate 2: Cucumis manni

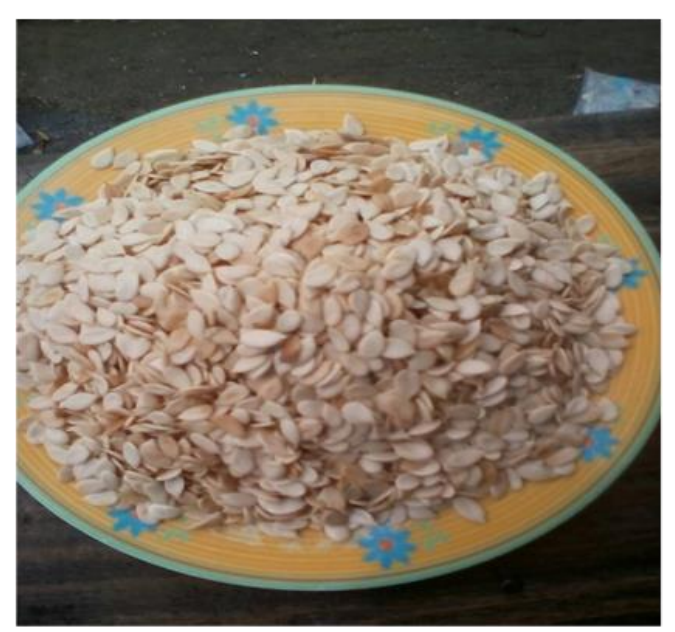

Plate 4: Citrullus vulgaris

\section{RESULTS AND DISCUSSION}

\section{Effect of varietal difference on the proximate composition of melon seeds}

Proximate analysis of the four varieties of melon seeds revealed low moisture content ranging from 4.30 to $6.19 \%$ as presented in Table 2. Citrullus colocynths had significantly $(p<0.05)$ low moisture value of $4.30 \%$ while Cucumis melo had significantly high value (6.26\%) compared to other varieties. Fokou et al. (2004) reported a moisture content that ranged from 4.33 to $7.26 \%$ for five different melon seeds. Azhari et al. (2014) and lbeto et al. (2012) also reported moisture content of melon seeds to be in the range of 4.27 to $5.63 \%$. These values are within the range observed in this study. Hence, these values are low which is an indication that these melon seeds can be stored for a long period of time.

Ash content of the selected melon seed varieties ranged from 2.57 to $4.40 \%$. The ash content was significantly 
Table 1. Recipe formulation for the Egusi soup.

\begin{tabular}{lcccc}
\hline Ingredients & C. melo & C. manni & C. colocynths & C. vulgaris \\
\hline Melon Seed Flour $(\mathrm{g})$ & 500.0 & 500.0 & 500.0 & 500.0 \\
Palm oil (ml) & 150.0 & 150.0 & 150.0 & 150.0 \\
Onion (g) & 10.0 & 10.0 & 10.0 & 10.0 \\
Salt $(\mathrm{g})$ & 10.0 & 10.0 & 10.0 & 10.0 \\
Water (ml) & 500.0 & 500.0 & 500.0 & 500.0 \\
Pepper (g) & 5.0 & 5.0 & 5.0 & 5.0 \\
Magi (g) & 9.0 & 9.0 & 9.0 & 9.0 \\
\hline
\end{tabular}

Source: Kiin-kabari and Akusu, 2017.

Table 2. Proximate Composition of Melon Seed Flours.

\begin{tabular}{lcccccc}
\hline Samples & Moisture (\%) & Ash (\%) & Fat (\%) & Protein (\%) & $\begin{array}{c}\text { Crude fibre } \\
(\%)\end{array}$ & $\begin{array}{c}\text { Carbohydrates } \\
(\%)\end{array}$ \\
\hline Cucumis melo & $6.26 \pm 0.13^{\mathrm{a}}$ & $4.40 \pm 0.00^{\mathrm{a}}$ & $47.14 \pm 1.87^{\mathrm{b}}$ & $33.37 \pm 000^{\mathrm{b}}$ & $4.51 \pm 0.00^{\mathrm{b}}$ & $0.11 \pm 0.04^{\mathrm{b}}$ \\
Cucumeropsis manni & $6.19 \pm 0.65^{\mathrm{a}}$ & $3.15 \pm 0.00^{\mathrm{b}}$ & $50.82 \pm 0.25^{\mathrm{a}}$ & $33.03 \pm 0.09^{\mathrm{c}}$ & $3.92 \pm 0.12^{\mathrm{c}}$ & $2.90 \pm 0.42^{\mathrm{a}}$ \\
Citrullus colocynths & $4.30 \pm 0.06^{\mathrm{b}}$ & $2.57 \pm 0.16^{\mathrm{d}}$ & $52.52 \pm 0.54^{\mathrm{a}}$ & $34.81 \pm 0.00^{\mathrm{a}}$ & $5.51 \pm 0.00^{\mathrm{a}}$ & $0.92 \pm 0.10^{\mathrm{b}}$ \\
Citrullus vulgaris & $6.19 \pm 0.05^{\mathrm{a}}$ & $2.74 \pm 0.07^{\mathrm{c}}$ & $51.35 \pm 0.00^{\mathrm{a}}$ & $30.37 \pm 0.00^{\mathrm{d}}$ & $4.51 \pm 0.00^{\mathrm{b}}$ & $3.16 \pm 1.23^{\mathrm{a}}$ \\
LSD & 1.10 & 0.24 & 3.13 & 0.15 & 0.19 & 1.91 \\
\hline
\end{tabular}

$a, b, c$ Values with the same superscript within the same column do not differ significantly $(p>0.05) . \pm$ Mean scores of duplicate determinations.

$(\mathrm{p}<0.05)$ higher in Cucumis melo $(4.40 \%)$ while it was least in Citrullus colocynth (2.57\%). Azhari et al. (2014) and Obasi et al. (2012) found ash content of melon seeds to range from 2.40 to $4.33 \%$ while Akusu and Kiin-kabari (2015) reported $3.33 \%$. The results showed that the melon varieties in the present study have significant amount of ash which are important sources of minerals.

Fat content of the melon seed varieties varied from 47.14 to $52.52 \%$ and showed no significant $(p<0.05)$ difference among the varieties except for Cucumis melo. Citrullus colocynth showed a higher content of fat $(52.52 \%)$ than other varieties. Similar findings were reported by lbeto et al. (2012) and Mian-Hao and Yanson (2007). All the melon seed varieties studied had high fat contents. Hence, the seeds are classified as excellent sources of dietary oil (Abiodun and Adeleke, 2010).

The protein content of the selected melon seed varieties ranged from 30.37 to $34.81 \%$. There was a significant difference in the protein content of the melon seeds and Citrullus colocynth $(34.81 \%)$ had significantly higher value than other varieties. Fokou et al. (2004) reported a range of 24.30 to $41.60 \%$ for five melon seeds while Azhari et al. (2014) and De Mello et al. (2001) reported 11.67 to $35.0 \%$. These melon seed varieties are rich in crude protein content and could be used to enrich food products.

Crude fibre ranged from $3.92 \%$ in Cucumeropsis manii variety to $5.51 \%$ in Cittrullus colocynth variety. In a study by Abiodun and Adeleke (2010), the fibre content of four different melon seeds ranged from 1.66 to $2.16 \%$. Crude fibre contents of 0.90 to $1.63 \%$ were reported by Fokou et al. (2004) while Loukou et al. (2007) reported crude fibre of 2.30 to $2.94 \%$. These values are low compare to the value observed in this study. This difference could be attributed to the level of drying temperature applied and the season at which the study was conducted. There is a natural phenomenon that food materials are moister during rainy season than in dry season.

The results for total carbohydrate were between $0.11 \%$ and $3.16 \%$ with C. melo and C. vulgaris having the lowest and highest values, respectively. Raji and Orelaja (2014) reported $3.14 \%$ for Cucumis melo seeds which is higher than $0.11 \%$ obtained from this study. From this result, these melon seed varieties cannot be considered as potential sources of carbohydrate.

\section{Effect of varietal difference on the functional properties of melon seeds}

The selected functional properties of melon seed flours are shown in Table 3. Oil absorption capacity of the melon seed varieties ranged from 2.10 to $2.55 \mathrm{~g} / \mathrm{ml}$ with $C$. melo $(2.30 \mathrm{~g} / \mathrm{ml})$ and $C$. vulgaris $(2.55 \mathrm{~g} / \mathrm{ml})$ having significantly $(p<0.05)$ higher values than $C$. colocynth and $C$. manni $(2.10 \mathrm{~g} / \mathrm{ml}$ in both species). This indicates that $C$. vulgaris and $C$. melo may have higher flavour retention than other varieties. Invariably, high oil absorption capacities showed that the melon seeds increase mouth feel when used in food preparations such as meat analogues (Eke and Akobundu, 1993). The oil absorption values obtained in this study were higher than the findings of PeterIkechukwu et al. (2016) who reported a range of 1.35 to 
Table 3. Selected functional properties of melon seed flours.

\begin{tabular}{lcccc}
\hline Samples & $\begin{array}{c}\text { Oil Absorption } \\
(\mathbf{g} / \mathbf{m l})\end{array}$ & $\begin{array}{c}\text { Water Absorption } \\
(\mathbf{g} / \mathbf{m l})\end{array}$ & $\begin{array}{c}\text { Bulk Density } \\
(\mathbf{g} / \mathbf{g})\end{array}$ & $\begin{array}{c}\text { Least Gelation } \\
\text { Concentration }(\%)\end{array}$ \\
\hline Cucumis melo & $2.30 \pm 0.21^{\mathrm{a}}$ & $1.26 \pm 0.14^{\mathrm{a}}$ & $0.54 \pm 0.00^{\mathrm{b}}$ & - \\
Cucumeropsis manni & $2.10 \pm 0.00^{\mathrm{b}}$ & $1.37 \pm 0.07^{\mathrm{a}}$ & $0.58 \pm 0.00^{\mathrm{b}}$ & 2.00 \\
Citrullus colocynths & $2.10 \pm 0.28^{\mathrm{b}}$ & $1.29 \pm 0.03^{\mathrm{a}}$ & $0.67 \pm 0.04^{\mathrm{a}}$ & - \\
Citrullus vulgaris & $2.55 \pm 0.00^{\mathrm{a}}$ & $1.45 \pm 0.05^{\mathrm{a}}$ & $0.60 \pm 0.02^{\mathrm{a}}$ & 4.00 \\
LSD & 0.43 & 0.25 & 0.06 & \\
\hline
\end{tabular}

$a, b, c$ Values with the same superscript within the same column do not differ significantly $(p>0.05)$. \pm Mean scores of duplicate determinations.

Table 4. Means sensory evaluation of Egusi soups prepared from different varieties of melon.

\begin{tabular}{lcccccc}
\hline Samples & Appearance & Taste & Flavour & $\begin{array}{c}\text { Water } \\
\text { Separation }\end{array}$ & Thickness & $\begin{array}{c}\text { Overall } \\
\text { Acceptability }\end{array}$ \\
\hline Cucumis melo & $7.00^{\mathrm{b}}$ & $7.00^{\mathrm{ab}}$ & $6.80^{\mathrm{ab}}$ & $6.53^{\mathrm{bc}}$ & $6.60^{\mathrm{bc}}$ & $7.53^{\mathrm{ab}}$ \\
Cucumeropsis manni & $6.67^{\mathrm{b}}$ & $6.47^{\mathrm{b}}$ & $6.20^{\mathrm{b}}$ & $5.93^{\mathrm{c}}$ & $6.20^{\mathrm{c}}$ & $6.87^{\mathrm{b}}$ \\
Citrullus colocynths & $7.00^{\mathrm{b}}$ & $6.60^{\mathrm{b}}$ & $6.87^{\mathrm{ab}}$ & $7.13^{\mathrm{ab}}$ & $7.47^{\mathrm{ab}}$ & $7.27^{\mathrm{ab}}$ \\
Citrullus vulgaris & $8.07^{\mathrm{a}}$ & $7.80^{\mathrm{a}}$ & $7.40^{\mathrm{a}}$ & $7.67^{\mathrm{a}}$ & $8.07^{\mathrm{a}}$ & $7.93^{\mathrm{a}}$ \\
LSD & 0.75 & 0.87 & 1.02 & 0.84 & 0.89 & 0.75 \\
\hline
\end{tabular}

$a, b, c$ Means with the same superscript within the same column do not differ significantly $(p>0.05) . \pm$ Mean scores of duplicate determinations.

\section{$1.57 \mathrm{~g} / \mathrm{ml}$.}

There was no significant difference $(p>0.05)$ in water absorption capacity of the melon seed varieties with values ranging from 1.26 to $1.45 \mathrm{~g} / \mathrm{ml}$ for $C$. melo and C. vulgaris, respectively. Peter-lkechukwu et al. (2016) reported a range of 1.79 to $3.40 \mathrm{~g} / \mathrm{ml}$ for melon seeds from five varieties. High water absorption capacity is attributed to loose structure of starch polymers while low values is an indication of compactness of the structures (Adebowale et al., 2005). The water absorption capacity of the melon seed varieties showed that they can all be used as thickeners in the preparation of soup and stew.

Bulk density of the melon seeds ranged from 0.54 to 0.67 $\mathrm{g} / \mathrm{ml}$ for C. melo and C. colocynth varieties with significantly low and high values, respectively. Citrullus vulgaris with the value of $0.60 \mathrm{~g} / \mathrm{ml}$ showed no significant difference with $C$. colocynth. This showed that seeds of $C$. colocynths and $C$. vulgaris are denser than other melon seed varieties. High bulk density is desirable since it helps to reduce paste thickness and ease the dispensability of food powders (Udensi and Okaka, 2008). This could be the reason why $C$. vulgaris is regularly and comfortably being used in soup making. According to Karuna et al. (1996), bulk density of foods increases with increase in starch content. This therefore places $C$. vulgaris and $C$. colocynths at advantage over C. manni and C. melo for use as food condiment in the preparation of stews and soups.

The least gelation concentration can be described as a measure of the minimum amount of starch needed to form a gel in a given volume of water (Adebowale et al., 2005).
Results show that Citrullus vulgaris and $C$. manni has good gelling properties than Citrullus Colocynths and Cucumis melo.

\section{Sensory properties of Egusi soups}

Effect of varietal difference on the sensory properties of egusi soups prepared from varieties of melon seeds are shown in Table 4. The result revealed that $C$. vulgaris was most preferred for all sensory parameters. This may be because this variety is mainly consumed and cherished more than all other varieties. The taste, flavour and overall acceptability of the soup prepared from $C$. melo showed no significant difference from $C$. vulgaris while flavour, water separation, thickness and overall acceptability of $C$. colocynths showed no significant $(p>0.05)$ difference with $C$. vulgaris. Soup prepared from C. manni was least preferred for all sensory parameters. The seeds of $C$. manni are bitter and this could be the reason of its low preference.

\section{Conclusion}

This study demonstrated that underutilised melon species such as C. melo, C. manni and C. colocynths can be good substitutes to the popularly known specie (C. vulgaris) in soup formulations and preparation. They are also good sources of fats and protein with appreciable functional properties that could be suitable for innovative applications in the food Industry. The sensory results equally showed 
that $C$. colocynths and $C$. melo compared favourably with C. vulgaris. Hence, can be used to replace it in the preparation of egusi soup.

\section{CONFLICT OF INTEREST}

The authors declare that they have no conflict of interest.

\section{REFERENCES}

Abiodun, M. A., \& Adeleke, R. O. (2010). Comparative studies on nutrition composition of melon seed flour varieties. Pakistan Journal of Nutrition, 9(9), 905-908.

Adebowale, A. A., Sanni, L. O., \& Awonarin, S. O. (2005). Effect of texture modifiers on the physico-chemical and sensory properties of dried fufu. Food Science and Technology International, 11(5), 373-382.

Akpambang, V. O. E., Amoo, I. A., \& Izuagle, I. (2008). Comparative compositional analysis on two varieties of melon (Colocynthis citrullus and Cucumeropsis) and a variety of Almond (Prunus amygdalus). Resource Journal of Agriculture and Biological Science, 4, 639-642.

Akusu, M. O., \& Kiin-kabari, D. B. (2015). Comparative studies on the physicochemical and sensory properties of watermelon (Citrullus lanatus) and Melon (Citrullus vulgaris) Seed Flours Used in "egusi" Soup Preparation. Journal of Food Research, 4(5), 1-8.

AOAC (2012). Official methods of Analysis (18th ed.; W. Horwitz, Ed.). Gaithersberg, MD: Association of Official Analytical Chemists.

Arisa, N. N., Adelakan, A. O., Alamu, A. E. \& Ogunfowora, E. J. (2013). The effect of pretreatment of plantain (Musa paradisiaca) flour on the pasting and sensory characteristics of Biscuit. International Journal of Food and Nutrition Science, 2(1), 10-23.

Azhari, S., Xu, Y. S., Jiang, Q. X., \& Xia, W. S. (2014). Physicochemical properties and chemical composition of Seinat (Cucumis melovar. tibish) seed oil and its antioxidant activity. Grasas y Aceites, 65(1), 8-12.

Chen, L., Kang, Y. H. \& Suh, J. K. (2014). Roasting processed oriental melon (Cucumis melo L. var. makuwa Makino) seed influenced the triglyceride profile and the inhibitory potential against key enzymes relevant for hypoglycemia. Food Research International, 56, 236-242.

De Mello, M. L. S., Bora, P. S., \& Narain, N. (2001). Fatty and amino acids composition of melon (Cucumis meloVar. saccharinus) Seeds. Journal of Food Composition and Analysis, 14, 69-74.

Egbebi, A. O. (2014). Comparative studies on the three different species melon seed; (Citrulus vulgaries, Cucumeropsis manni and Leganaria siceraria). Sky Journal of Food Science,3, 1-4.

Eke, O. S., \& Akobundu, E. N. T. (1993). Functional properties of African yam beans (Sphenostylis stenocarpa) seed flour as affected by processing. Journal of Food Chemistry, 48, 337340.

Elkhalifa, A. O., Schiffler, B., \& Bernhardt, R. (2005). Effect of fermentation on the Functional properties of sorghum flour. Food Chemistry, 92, 1-5.

Fokou, E., Achu, M. B., \& Tchounguep, F. M. (2004). Preliminary nutritional evaluation of five species of egusi seed in Cameroon. African Journal of Food, Agriculture, Nutrition and Development, 4, 8.
Ibeto, C. N., Okoye, C. O. B., \& Ofoefule, A. U. (2012). Comparative study of the physicochemical characterization of some oils as potential feedstock for biodiesel production. ISRN Renewable Energy, 5p. Article ID: 621518.

Jacob, A. G., Etong, D. I., \& Tiijani, A. (2015). Proximate, Mineral and Anti-nutritional composition of melon (Citrulus lanatus) seeds. British Journal of Research, 2(5), 142-151.

Karuna, D., Noel, G., \& Dilip, K. (1996). Editorial address. Food and Nutrition Bulletin. United Nations University Press, Tokyo, Japan, 17, 2.

Kiin-Kabari, D. B., \& Akusu, O. M. (2017). Production, proximate, functional and organoleptic assessment of Ready-To-Cook "Ogbono"/“Egusi” seeds premix (Dry mix powder). International Journal of Food Science and Nutrition, 2(1), 8285.

Loukou, A. L., Nakri, D. G. Y. Dje, A., Ippre, V. K., Alice, M. M., Audoin, J. P. B., \& Zoro, B. I. A. (2007). Macronutrient composition of three cucurbit species cultivated for seed consumption in Cote d'Ivoire. African Journal of Biotechnology, 6(5), 529-533.

Mian-Hao, H., \& Yansong, A. (2007). Characteristics of some nutritional composition of melon (Cucumis melo hybrid "ChunLi") seeds. International Journal of Food Science and Technology, 42, 1397-1401.

Obasi, N. A., Ukadilonu, J., Eze, E., Akubugwo, E. I., \& Okorie, U. C. (2012). Proximate composition, extraction, characterization and comparative assessment of coconut (Cocos nucifera) and melon (Colocynthis citrullus) seeds and seed oils. Pakistan Journal of Biological Sciences, 15, 1-9.

Ogbuonye, E. O. (2017). Varietal difference on the proximate, mineral component and vitamin contents of named local and foreign rice water. Specialty Journal of Biological Sciences, $3(4), 51-57$

Ogundele, J. O., \& Oshodi, A. A. (2010). Proximate composition and some functional properties of three varieties of Lagenaria Siceraria Melon seeds. Resource Journal of Agriculture and Biological Science, 6(2), 108-112.

Onyeike, E. N., \& Achera, G. N. (2002). Chemical composition of selected Nigerian oil seeds and physicochemical properties of the oil extracted. Food Chemistry, 77, 431-437.

Peter-lkechukwu, A., Ojukwu, M., Kabuo, N. O., Omeire, G. C., \& Bede, E. N. (2016). Comparative Evaluation of Proximate Compositions, Functional and Physicochemical Properties of Raw Melon Seeds of Five Members of Cucurbitaceae Family. American Journal of Food Science and Nutrition, 3(1), 8-17.

Raji, O. H., \& Orelaja, O. T. (2014). Nutritional composition and oil characteristics of gold melon (Cucumis melo) seeds. Food Science and Quality Management, 27, 18-21.

Sathe, S. K., \& Salunkhe, D. K. (1981). Functional properties of Great Northern bean (Phaseolus vulgaris). Journal of Food Science, 46, 71-75.

Udensi, E. A., \& Okaka, J. C. (2008). Mathematical Modeling of some functional properties of Mucuna cochinchinesis. Nigerian Food Journal, 26(1), 119-129.

Yusuf, A. A., Adewuyi, S., \& Lasisi, A. A. (2006). Physicochemical composition of leaves, meals and oils of fluted pumpkin (Telfairia occidentalis) and melon (Citrullus vulgaris). Journal of Agriculture, 1, 32-35. 